\title{
A clinical study of Chirabilva ghanavati in Hyperlipidemia
}

\author{
Research Article
}

\section{Dhiraj Kumar Vishwakarma ${ }^{1^{*}}$, Bulusu Sitaram², Paramkusha Rao $\mathbf{M}^{3}$}

1. PG Scholar, 2. Professor, 3. Professor \& HOD

Department of Dravyaguna, SV Ayurvedic College, Tirupati

\begin{abstract}
Hyperlipidaemia is a general term for elevated concentrations of any or all of the lipids in the plasma, including hyperlipoproteinemia, hypercholestrimia etc. Hyperlipidaemia is concerned as the cause for coronary heart diseases and atherosclerosis which results from slow but sure deposition of lipids in the arteries is a chief cause of mortality worldwide. Aim of this study is to evaluate antihyperlipidaemic activity of Chirabilva Ghanavati prepared from bark and heart wood of Chirabilva (Holoptelia integrifolia (Roxb.) Planch.). The patients suffering from Hyperlipidaemia and its related disorders like non-insulin dependent diabetes etc. were selected randomly and divided into two groups, each group contains 15 patients. The patients of group A were advised to take Chirabilva Ghanavati prepared from stem bark. The patients of group B were advised to take Chirabilva Ghanavati prepared from heart wood. The overall result showed that Chirabilva Ghanavati prepared from the stem bark was more effective than Chirabilva Ghanavati prepared from the heart wood in Hyperlipidaemia.
\end{abstract}

Keywords: Hyperlipidaemia, Hyperlipoproteinemia, Hypercholestrimia, Chirabilva Ghanavati, Atherosclerosis, Coronary heart diseases.

\section{Introduction}

Ayurveda descended on the earth more than three millenniums ago, with the great tapas, made by seers like Bharadvaja for the welfare of the mankind. (1) The main utility of Ayurveda is-

- To maintain the health of the healthy individual and

- To cure the disease of a patient (2)

For the maintenance of the health of a healthy individual, there are many things described in Ayurveda such as Dinacharya, Ritucharya, Quantitative dietetics, Qualitative dietetics, Swasthavritta, Sadavritta etc. If a healthy individual fails to follow these things, then he may suffer from several diseases as in the case of Medovriddhi.

Absence of physical activity, sleeping during day and intake of foods which increase Kapha, make the end product of digestion (abnormally) sweet which in turn causes increase of Medas (fats). This increased Medas obstructs the nutrient channels of remaining tissues depriving them of nutrition. (3) Fat accumulated in large quantity in the body leads to Abaddha Medovriddhi or Hyperlipidaemia.

Today is the era of modernization and fast life. Everybody is busy and leading a stressful life. Consumption of fast foods having high calorific value

\section{*Corresponding Author:}

Dhiraj Kumar Vishwakarma

PG scholar, Department of Dravyaguna

SV Ayurvedic College,

Tirupati, Andhra Pradesh, India -517507.

E-mail: dhirajvishwa11@gmail.com is also increasing. People have every comfort of living and they are not doing any kind of physical activity and so the body fats along with cholesterol are increasing in their body, which invites the disorders like Hypertension, Heart diseases and Hyperlipidaemia. (4)

The industrialization, stress during the work, dietary habits, lack of exercise and intake of various varieties of junk food among the daily diet e.g. fast food, frozen fruits, increased amount of soft drinks and beverages, canned foods results into the disturbance of Agni or metabolism and ultimately leads to clinical entity known as Hyperlipidaemia. (4)

Hyperlipidaemia is a general term for elevated concentrations of any or all of the lipids in the plasma, including hyperlipoproteinemia, hypercholesterolemia, etc. (5) Hyperlipidaemia is concerned as the cause for coronary heart diseases and atherosclerosis which results from slow but sure deposition of lipids in the arteries is a chief cause of mortality worldwide. (6)

Coronary Heart Disease (CHD) is the number one killer among the diseases and it accounts for $37 \%$ of adult deaths in the US every year. (7) Nikolai Anichkov in 1912 discovered the role of cholesterol in CHD, currently the world's most deadly disease. (8) CHD is the commonest cause of death in the UK. Average level of cholesterol is $12 \%$ higher in the UK population than in the USA and $80 \%$ of UK adults have a total cholesterol level above $200 \mathrm{mg} / \mathrm{dl}$. In India, persons suffering from the CHD are doubled in the last 20 years. (9) In South India, CHD incidences are $7.4 \%$ in rural area and $13.9 \%$ in urban area, which is higher than North India (Rural- 3\% and urban 9.7\%). (10) Mortality from cardiovascular disorders in India is 430/100000 in both sexes and in males it is 460 whereas in females it accounts for $400 / 100000$ deaths per year. (11) The 
mean cholesterol in urban India is $190 \mathrm{mg} / \mathrm{dl}$ whereas in rural area it is $150 \mathrm{mg} / \mathrm{dl}$. (12) Raised Cholesterol (>220 $\mathrm{mg} / \mathrm{dl}$ ) is prevalent in $60 \%$ population of $50-59$ years age group and $55 \%$ population in $60-100$ years age group in females in India whereas in males it is prevalent in $45 \%$ individuals of $40-49$ years age group. (13) From point of view of High-density lipoproteins (HDL), $28.2 \%$ males and $12.9 \%$ females have HDL below $1 \mathrm{mmol} / \mathrm{L}$. (14) Punjab state has the highest population suffering from heart disorders including ischemic heart disease (IHD) and Hypertension (HT).

\section{Aims and Objectives}

To evaluate antihyperlipidaemic activity of Chirabilva Ghanavati prepared from bark and heart wood of Chirabilva (Holoptelia integrifolia (Roxb.) Planch.).

\section{Materials and Methods Selection of Patients}

- Persons suffering from dyspnoea on exertion, weight gain, obesity, diabetes mellitus and hypertension were screened for Hyperlipidaemia.

- As the hyperlipidemic state is leading to many of the above said conditions, such patients were selected for the experimental trial.

- The cases were registered from the O.P.D. of the S.V. Ayurvedic College/ Hospital and were selected for the study.

\section{Praparation of Medicine \\ Collection of drug}

The stem bark and heart wood of the drug Chirabilva was collected from the natural sources in and around Tirupati. The bark and heart wood were then thoroughly cleaned, cut into pieces, dried and powdered.

\section{Preparation of Kashaya}

In order to prepare medicine, first Kashaya was made. The ratio of drug and water was 1: 16. The powdered bark and heart wood were then weighed and 16 times water was added separately to them and was boiled till it got reduced to $1 / 4$ th. The filtered part, known as Kashaya, was prepared from both the part separately.

Weight of the drug (Heart wood or bark) - $16 \mathrm{~kg}$

Water - 256 litres

Reduced to $1 / 4^{\text {th }}$ i.e. $\quad-64$ litres

\section{Preparation of Rasakriya}

Thus the obtained Kashaya was filtered through a cloth and then it was made into Rasakriya.

According to the principle,

\section{Kwathadinampunah pakatghantvamsararasakriya.}

The Kashaya was again boiled and after it attained a semisolid consistency, it was further heated and after it got dried it was scraped out of the boiler.

\section{Preparation of granules}

The obtained material was put inside the granule making machine and granules of the scraped material was obtained.

\section{Preparation of tablets}

- Talc was added to it and further it was put into tablet making machine and tablets weighing $500 \mathrm{mg}$ were prepared.

- The said procedure was conducted at Srinivasa Ayurveda Pharmacy, Srinivasa Mangapuram, Tirupati.

- The above procedure was undertaken to avoid difficulty in administration of the drug to patients on OP basis.

- The patients were given a packet of medicine with 60 tablets in it.

\section{Rationality of selecting the drug:}

- Acharya Charak has mentioned under Lekhaniya Mahakashaya. (16)

- Easily available.

- Cheap

- No previous work was found on its heart wood.

- Most of the previous works are done on bark and leaves as an anti-inflammatory, analgesic, on piles, on diabetes etc.

- Modern anti-hyperlipidaemics like statins are found to have many adverse reactions;

Hence it is the need of the hour to find an alternative drug in other systems of medicine. So in the present study Chirabilva Ghanavati was taken as a test drug in Hyperlipidemia.

\section{Inclusion criteria}

Patients suffering from Hyperlipidaemia and its related disorders like non-insulin dependent diabetes in the age group of $30-60$ years.

\section{Exclusion criteria}

- Patients below 30 years and above 60 years of age.

- Patients suffering from Insulin-Dependent Diabetes Mellitus (I.D.D.M.), severe diabetes mellitus with complications, malignant disorders and renal disorders.

- Patients who have a previous history of cardiac or cerebral stroke and also in patients who underwent by-pass surgery.

\section{Pathological investigations}

Following investigations will be carried out before and after treatment.

- Hematological investigations - Hemoglobin (Hb), Total Leukocyte Count (TLC), Differential Leukocyte Count (DLC), Erythrocyte Sedimentation Rate (ESR).

- Urine analysis -Routine and Microscopic.

- Biochemical examinations - Post-Prandial Blood Sugar (PPBS), Fasting Blood Sugar (FBS), Lipid profile. 
Diagnostic criteria

Patients were diagnosed on the basis of Lipid Profile. Any one or more of the following criteria were selected.

- Serum cholesterol (201 mg/dl or more)

- Serum Triglycerides $(151 \mathrm{mg} / \mathrm{dl}$ or more)

- High-density lipoproteins (HDL) $<35 \mathrm{mg} / \mathrm{dl}$

\section{Grouping}

The patients suffering from Hyperlipidaemia and its related disorders were selected randomly and divided into two groups.

1. Group -A: The patients of group A were advised to take Chirabilva Ghanavati prepared from stem bark

2. Group-B: The patients of group Bwere advised to take Chirabilva Ghanavati prepared from heart wood.

\section{Follow Up:}

After completion of the treatment, the patients of both the groups have been examined during follow ups at the interval of two weeks.

\section{Duration of treatment}

The course of the treatment was fixed as 45 days. The patients were instructed to avoid diet which can increase fat like oily food, butter, eggs, meat etc. Preliminary data was collected before treatment.

\section{Dose}

The patients were given 4 tablets (each tablet weighing $500 \mathrm{mg}$ ) per day, 2 tablets in the morning and 2 tablets in the evening with water.

\section{Plan of data analysis}

The data according to parameters (lipid profile) were validated and subjected for statistical evaluation and significance of result is mentioned according to ' $\mathrm{P}$ ' value. The overall result is mentioned according to percentage of relief and relief in number of parameters. If all five parameters comes within normal range, the result is considered as 'Completely relieved'; if four parameters comes within normal range, the result is considered as 'Markedly relieved'; if three parameters comes within normal range, the result is considered as 'Moderately relieved'; if two or only one parameters become within normal range, the result is considered as 'Mildly relieved' and if no parameter come within normal range, the result is considered as 'Unchanged'. The normal values of parameters are given below-

Table No. 1: Normal values of lipid profile [17]

\section{Total Cholesterol}

$$
\begin{aligned}
& <200 \rightarrow \text { Desirable } \\
& 200-239 \rightarrow \text { Borderline } \\
& \geq 240 \rightarrow \text { High }
\end{aligned}
$$

LDL

$$
\begin{aligned}
& <100 \rightarrow \text { Optimal } \\
& 100-129 \rightarrow \text { Near optimal } \\
& 130-159 \rightarrow \text { Borderline } \\
& 160-189 \rightarrow \text { High } \\
& \geq 190 \rightarrow \text { Very High }
\end{aligned}
$$

VLDL

$<32 \rightarrow$ Desirable

HDL

$$
\begin{aligned}
& <40 \rightarrow \text { Low } \\
& \geq 60 \rightarrow \text { High }
\end{aligned}
$$

\section{Serum Triglycerides}

$$
\begin{aligned}
& <150 \rightarrow \text { normal } \\
& 150-199 \rightarrow \text { Borderline } \\
& 200-499 \rightarrow \text { High } \\
& \geq 500 \rightarrow \text { Very High }
\end{aligned}
$$

\section{Observations and results:}

Table No. 2: EFFECT OF MEDICINE ON LIPID PROFILE OF GROUP A PATIENTS

\begin{tabular}{|c|c|c|c|c|c|c|c|c|c|c|}
\hline \multirow{2}{*}{$\begin{array}{c}\text { Parame } \\
\text { ters }\end{array}$} & \multicolumn{2}{|c|}{$\begin{array}{c}\text { Mean } \\
(\mathbf{m g} / \mathbf{d I})\end{array}$} & \multirow{2}{*}{$\begin{array}{c}\text { Mean } \\
\text { diff. }\end{array}$} & \multicolumn{2}{|c|}{ S.D. } & \multicolumn{2}{|c|}{ S.E. } & \multirow{2}{*}{ 't' } & \multirow{2}{*}{ P } & \multirow{2}{*}{ Significance } \\
\cline { 2 - 3 } & B.T. & A.T. & & B.T. & A.T. & B.T. & A.T. & & & \\
\hline T.C. & 214.32 & 163.64 & 50.68 & 31.37 & 11.06 & 8.10 & 2.856 & 6.6309 & $<0.0001$ & $\begin{array}{c}\text { Extremely } \\
\text { significant }\end{array}$ \\
\hline L.D.L. & 140.47 & 95.60 & 44.87 & 37.84 & 10.62 & 9.77 & 2.74 & 5.1096 & 0.0002 & $\begin{array}{c}\text { Extremely } \\
\text { significant }\end{array}$ \\
\hline H.D.L. & 36.13 & 40.94 & -5.80 & 2.70 & 5.05 & 0.70 & 1.26 & 5.9079 & $<0.0001$ & $\begin{array}{c}\text { Extremely } \\
\text { significant }\end{array}$ \\
\hline V.L.D.L & 37.72 & 26.107 & 11.61 & 9.28 & 3.78 & 2.39 & 0.97 & 5.3365 & 0.0001 & $\begin{array}{c}\text { Extremely } \\
\text { significant }\end{array}$ \\
\hline T.G. & 188.60 & 130.53 & 58.07 & 46.42 & 18.90 & 11.99 & 4.88 & 5.3365 & 0.0001 & $\begin{array}{c}\text { Extremely } \\
\text { significant }\end{array}$ \\
\hline
\end{tabular}

$(\mathrm{n}=15, \mathrm{df}=14)$

The $\mathrm{P}$ value of all the parameters were below 0.05 , hence the results of treatment were very significant. 
Graph No. 1: EFFECT OF MEDICINE ON LIPID PROFILE OF GROUP A PATIENTS

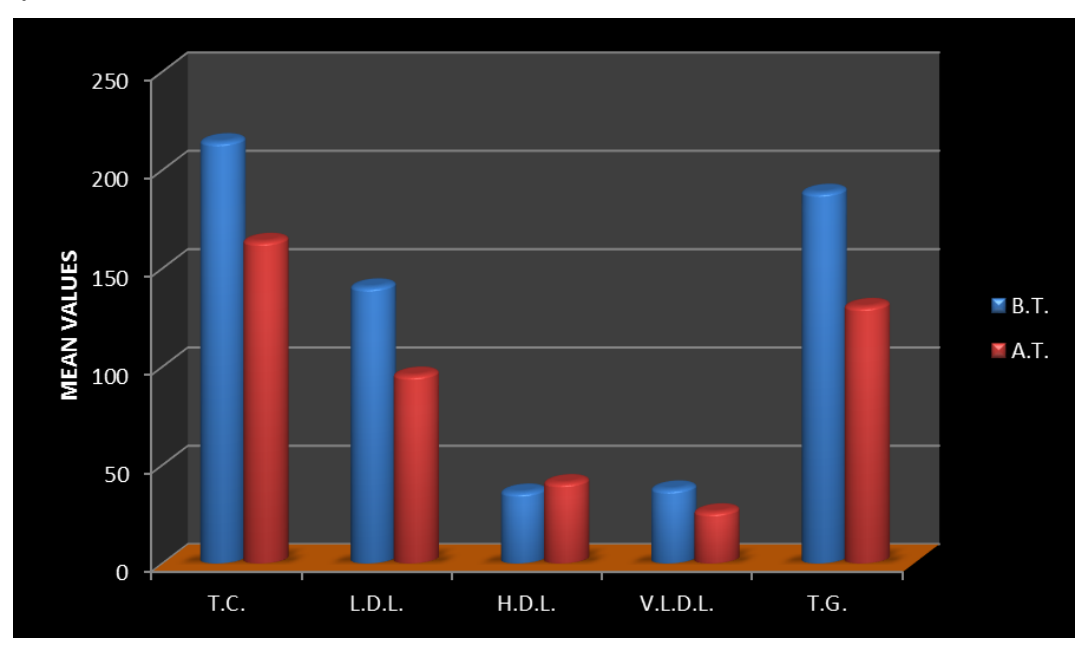

TABLE No. 3: EFFECT OF MEDICINE ON LIPID PROFILE OFGROUP B PATIENTS

\begin{tabular}{|c|c|c|c|c|c|c|c|c|c|c|}
\hline \multirow{2}{*}{$\begin{array}{c}\text { Paramet } \\
\text { ers }\end{array}$} & \multicolumn{2}{|c|}{$\begin{array}{c}\text { Mean } \\
\text { (mg/d) }\end{array}$} & \multirow{2}{*}{$\begin{array}{c}\text { Mean } \\
\text { diff. }\end{array}$} & \multicolumn{2}{|c|}{ S.D. } & \multicolumn{2}{|c|}{ S.E. } & \multirow{2}{*}{ 't' } & \multirow{2}{*}{ P } & \multirow{2}{*}{$\begin{array}{c}\text { Signifi } \\
\text { cance }\end{array}$} \\
\cline { 6 - 9 } T.C. & 220.73 & 181.60 & 39.13 & 28.60 & 13.46 & 7.38 & 3.47 & 5.7928 & $<0.0001$ & $\begin{array}{c}\text { Extrem } \\
\text { ely } \\
\text { signifi } \\
\text { cant }\end{array}$ \\
\hline L.D.L. & 145.13 & 103.93 & 41.20 & 31.73 & 10.89 & 8.19 & 2.81 & 4.7567 & $<0.0001$ & $\begin{array}{c}\text { Extrem } \\
\text { ely } \\
\text { signifi } \\
\text { cant }\end{array}$ \\
\hline H.D.L. & 36.60 & 41.93 & -5.33 & 2.41 & 5.85 & 0.62 & 1.51 & 3.2644 & 0.0029 & $\begin{array}{c}\text { Very } \\
\text { signifi } \\
\text { cant }\end{array}$ \\
\hline V.L.D.L. & 38.60 & 35.73 & 2.87 & 4.56 & 2.63 & 1.18 & 0.68 & 2.9693 & 0.0102 & $\begin{array}{c}\text { Signifi } \\
\text { cant }\end{array}$ \\
\hline T.G. & 193.27 & 179.53 & 13.73 & 23.25 & 12.88 & 6.00 & 3.33 & 2.7596 & 0.0154 & $\begin{array}{c}\text { Signifi } \\
\text { cant }\end{array}$ \\
\hline
\end{tabular}

$(n=15, d f=14)$

The $\mathrm{P}$ value of all the parameters were below 0.05 , hence the results of treatment were very significant.

Graph No. 2: EFFECT OF MEDICINE ON LIPID PROFILE OFGROUP B PATIENTS

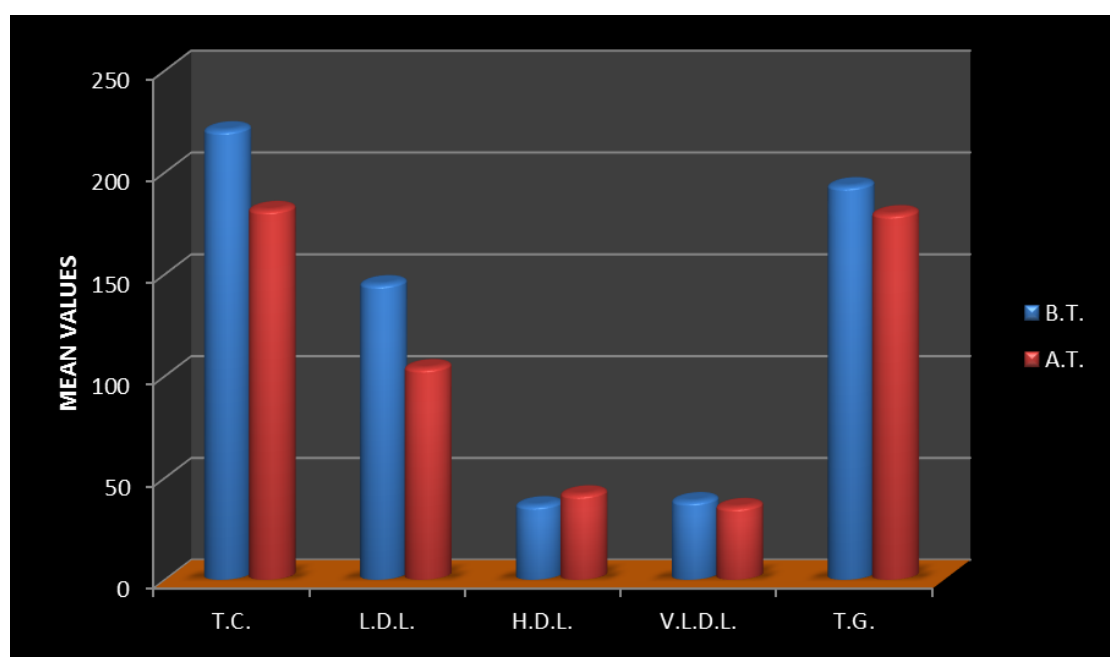




\section{OVERALL RESULT OF STUDY-}

TABLE No. 4: EFFECT OF MEDICINE ON GROUP 'A' PATIENTS

\begin{tabular}{|l|c|c|}
\hline \multicolumn{1}{|c|}{ Result } & No. of Patients & \% of patients \\
\hline Completely Relieved & 8 & 53.33 \\
\hline Markedly Relieved & 4 & 26.67 \\
\hline ModeratelyRelieved & 2 & 13.33 \\
\hline MildlyRelieved & 1 & 06.67 \\
\hline Unchanged & 0 & 0 \\
\hline
\end{tabular}

Graph No. 3: EFFECT OF MEDICINE ON GROUP 'A’ PATIENTS

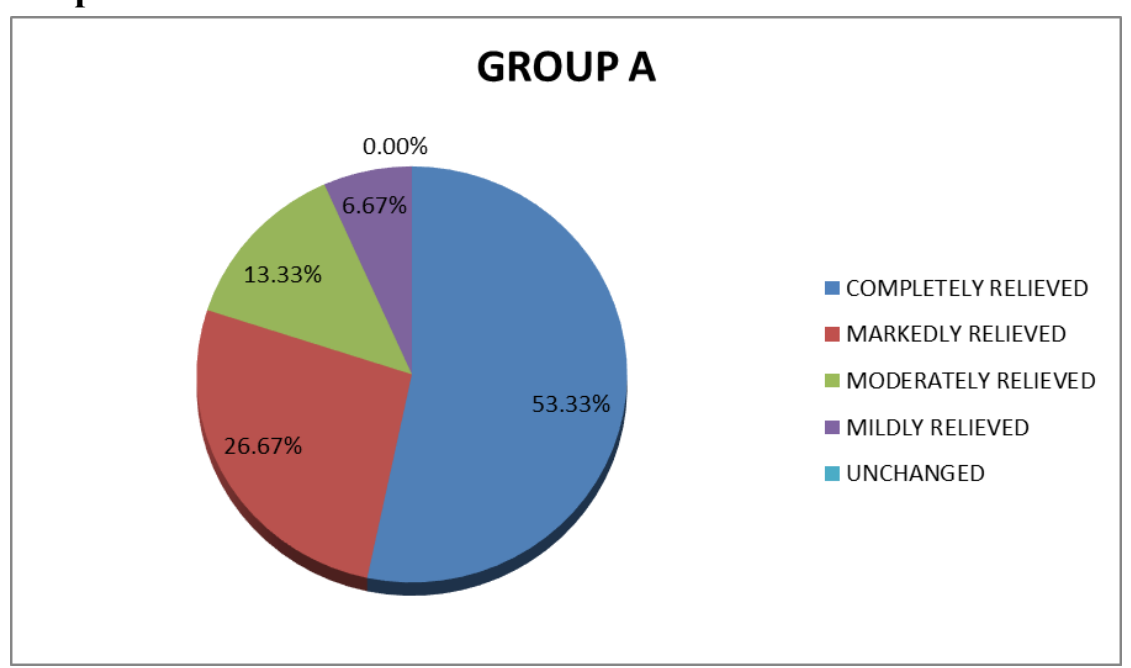

Out of 15 patients $53.33 \%$ patients got completely relief, $26.67 \%$ patients got marked relief, $13.33 \%$ patients got moderate relief and $06.67 \%$ patients got mild relief.

TABLE No. 5: EFFECT OF MEDICINE ON GROUP 'B' PATIENTS

\begin{tabular}{|l|c|c|}
\hline \multicolumn{1}{|c|}{ Result } & No. of Patients & \% of patients \\
\hline Completely Relieved & 1 & 06.67 \\
\hline Markedly Relieved & 7 & 46.66 \\
\hline Moderately Relieved & 6 & 40.00 \\
\hline Mildly Relieved & 1 & 06.67 \\
\hline Unchanged & 0 & 0 \\
\hline
\end{tabular}

Graph No. 4: EFFECT OF MEDICINE ON GROUP 'B' PATIENTS

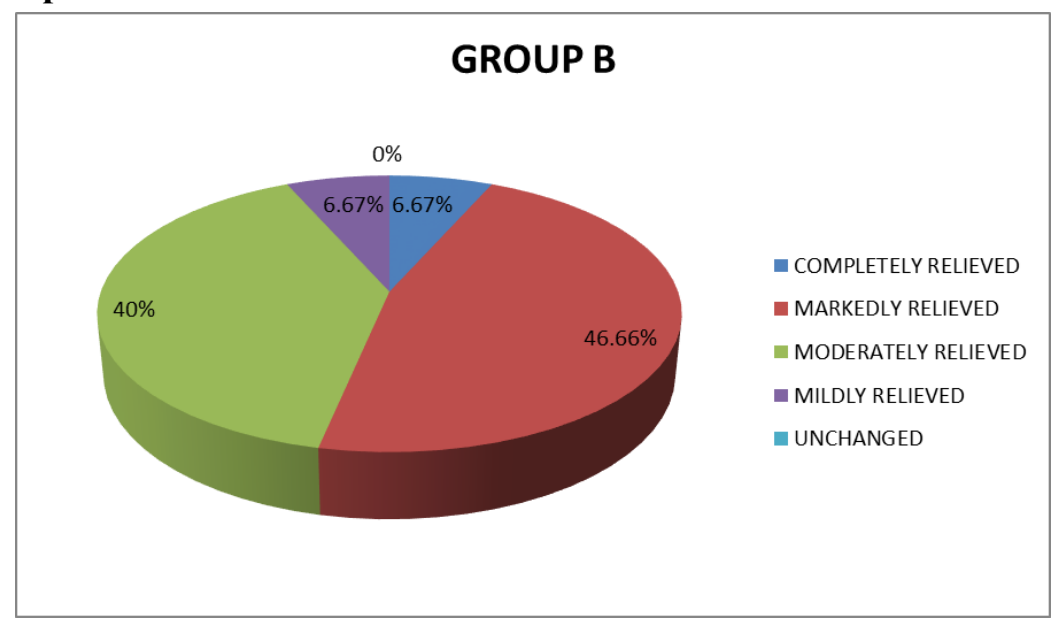

Out of 15 patients $06.67 \%$ patients got completely relief, $46.66 \%$ patients got marked relief, $40.00 \%$ patients got moderate relief and $06.67 \%$ patients got mild relief. 
OVERALL EFFECT OF MEDICINE ON GROUP 'A' \& GROUP 'B' PATIENTS

TABLE No. 6: OVER ALL EFFECT

\begin{tabular}{|c|l|c|c|}
\hline \multirow{2}{*}{ S.N. } & CHANGE IN & \multicolumn{2}{|c|}{ \% OF RELIEF } \\
\cline { 3 - 4 } & PARAMETERS & GROUP A & GROUP B \\
\hline 1. & TOTAL CHOLESTROL & 23.64 & 16.66 \\
\hline 2. & LDL & 31.95 & 25.42 \\
\hline 3. & HDL & -16.05 & -14.84 \\
\hline 4. & VLDL & 30.78 & 06.45 \\
\hline 5. & TRIGLYCERIDES & 30.79 & 06.07 \\
\hline
\end{tabular}

(* Negative sign in $\%$ of relief for HDL shows percentage of increase)

Graph No. 5: OVER ALL EFFECT

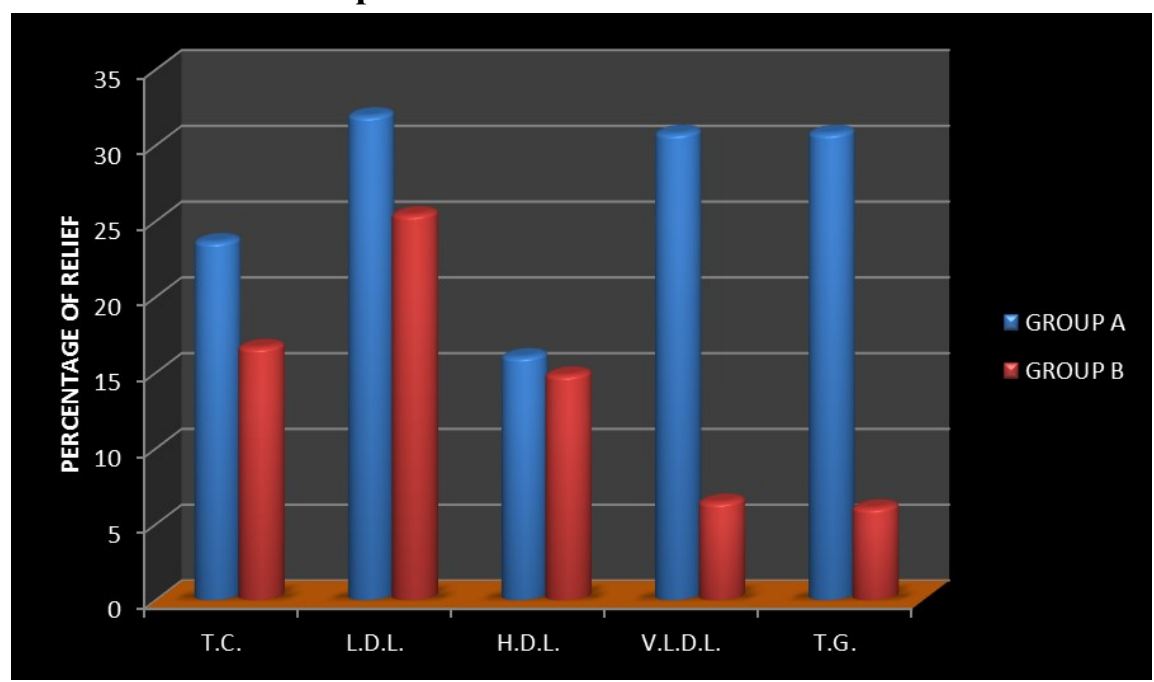

The overall result showed that the medicine used for group A patients was more effective than the medicine used for group B patients.

\section{Discussion \\ Effect of Therapies:}

The effect of therapy on group A patients shows that $53.33 \%$ patients got completely relief, $26.67 \%$ patients got marked relief, $13.33 \%$ patients got moderate relief and $06.67 \%$ patients got mild relief and the effect of therapy on group B patients shows that $06.67 \%$ patients got completely relief, $46.66 \%$ patients got marked relief, $40.00 \%$ patients got moderate relief and $06.67 \%$ patients got mild relief.

\section{Overall effect of medicine:}

The total cholesterol level of group A patients was reduced by $23.64 \%$ while of group B patients was reduced by $16.66 \%$. The L.D.L. level of group A patients was reduced by $31.95 \%$ while of group B patients was reduced by $25.42 \%$. The H.D.L. level of group A patients was increased by $16.05 \%$ while of group B patients was increased by $14.84 \%$. The V.L.D.L. level of groupA patients was reduced by 30.78 $\%$ while of group B patients was reduced by $06.45 \%$. The triglycerides level of group A patients was reduced by $30.79 \%$ while of group B patients was reduced by $06.07 \%$. All the results were statistically significant $(\mathrm{P}<0.05)$.

\section{Probable mode of action of drug:}

Chirabilva is the drug having Tikta, Kashaya
Rasa; Laghu, Ruksha Guna; Usna Virya; and Katu Vipaka. It acts on Meda by its Lekhana, Medohara Karma. Due to its Katu, Tikta Rasa it acts as Meda Upashoshaka. Tikta Rasa also acts as Upashoshaka of Vasa, Majja etc. Due to Laghu and Ruksha Gunas, it is reducing the excess of Abaddha Medas i.e. freely flowing fats in the circulation.

\section{Conclusion}

Chirabilva, one of the important drugs of Lekhaniya Dashemani, was taken as a trial drug to evaluate its anti hyperlipidaemic activity.

Almost all A charyas have mentioned Katu, Tikta Rasa; Laghu, Tikshna Guna; Usna Virya; Katu Vipaka for Chirabilva.

The patients of group A were treated with Chirabilva Ghanavati prepared from the stem bark and the patients of group B were treated with Chirabilva Ghanavati prepared from the heart wood.

On clinical examination it was found that out of 15 patients (Group A) $53.33 \%$ patients got complete relief, $26.67 \%$ patients got marked relief, $13.33 \%$ patients are moderate relief and $06.67 \%$ patients got mild relief after taking Ghanavati prepared from the stem bark.

Out of 15 patients (Group B) $06.67 \%$ patients got complete relief, $46.66 \%$ patients got marked relief, $40.00 \%$ patients got moderate relief and $06.67 \%$ 
patients got mild relief after taking Ghanavati prepared from the heart wood.

The overall result showed that Chirabilva Ghanavati prepared from the stem bark was more effective than Chirabilva Ghanavati prepared from the heart wood in Hyperlipidaemia.

\section{Acknowledgement:}

The authors are thankful to Dr. N.T.R. University of Health Sciences, Vijayawada, A. P., for their support to conduct the said research work.

\section{References}

1. Bulusu Sitaram. Bhavaprakasha of Bhavamisra. Chaukhambha Orientalia; Varanasi; 2006. 5p.

2. Pandit Kashinath Shastri. Charaka Samhita of Agnivesha. vol 1. Sutrasthan 30/26. Chaukhambha Sanskrit Sansthan; Varanasi; 2009. 587p.

3. Srivijayarakshit and Srikanthadatta. Madhavanidanam of Sri Madhavakara. 33/1, Chaukhamba Sanskrit Sansthan; Varanasi; 2003. $13 p$.

4. Anoop K. Pharmaco-Therapeutical Evaluation of Anti-Hyperlipidaemic Activity of Vacha (Acorus calamus Linn.) w.s.r. to Sthaulya. Department of
Dravyaguna. Institute for Postgraduate teaching and research in Ayurveda. Gujarat Ayurved University Jamnagar; 2010. 1p.

5. Dorland's illustrated Medical Dictionary. $27^{\text {th }}$ edition; 1985.

6. Swati Yadav et al. Antihyperlipidemic potential of herbals. Journal of Applied Pharmaceutical Research. January - March 2014; 9 (1); 7

7. Roan Shari. Cholesterol's Better Half. Indian Express. Nov. 20; 2006.

8. Anoop K. Pharmaco-Therapeutical Evaluation of Anti-Hyperlipidaemic Activity of Vacha (Acorus calamus Linn.) w.s.r. to Sthaulya. Department of Dravyaguna. Institute for Postgraduate teaching and research in Ayurveda. Gujarat Ayurved Universit Jamnagar; 2010. 1-2p.

9. Brahmanand Tripathi. Sarangadhara Samhita of Sarangadharacharya. Chaukhamba $\mathrm{Su}$ bharti prakashan; Varanasi; 2018. 212p.

10.Pandit Kashinath Shastri. Charaka Samhita of Agnivesha. vol 1. Sutrasthan 30/26. Chaukhambha Sanskrit Sansthan; Varanasi; 2009. 72p.

11.National Cholesterol Education Program . ATP III Guidelines At-A-Glance Quick Desk Reference; NIH Publication No. 01-3305; May 2001. 